\title{
Nahdlatul Ulama (NU): A Grassroots Movement Advocating Moderate Islam
}

\author{
Faried F. Saenong
}

\section{$\mathbf{1}$ \\ Introduction}

Pengurus Besar Nahdlatul Ulama (PBNU, the Central Board of Nahdlatul Ulama) claims to have 6o million members in Indonesia (Arifianto 2017: 257), and approximately 30 million more throughout the world. This makes NU the largest independent Islamic organisation across the globe. Its large number of members require extra attention from $\mathrm{PBNU}$ to adequately cater to their needs. In order to support services for the community, a broad range of institutions and infrastructures are necessary. To this end, NU boards have extended their exposure through Pengurus Besar (the central board) in Jakarta, Pengurus Wilayah (regional boards in provinces), Pengurus Cabang (branch boards in towns or districts), Majelis Wakil Cabang (councils of branch representatives in kecamatan or sub-districts), and Pengurus Ranting (twig boards in kelurahan or villages) across Indonesia. For overseas members, NU has launched Pengurus Cabang Istimewa (special branch boards) in many countries. In addition, NU has semi-autonomous organisations for women, university students, school or madrasa students, scholars, business people, and others, that extend from the central board to the twig boards.

The services to the members and communities also require significant attention as they include formation, supervision, leadership on all levels, direction, visits, and other organisational necessities. The services also include organisational workshops and training in order to provide information regarding NU's history, theology, activities, products, networks, political policies and strategies, and future projections. Equally important, NU also provides amenities such as hospital and health services, educational institutions from schools to universities, agricultural groups, and many more. NU provides services for nonmembers too, since leaders Ahmad Siddiq and Abdurrahman Wahid formally accepted "the official state ideology of Pancasila as its 'sole basis'" (Fealy and Bush 2014: 546) at the movement's National Congress in 1984. For a traditional socio-religious organisation like $\mathrm{NU}$, it is a substantial commitment to provide such services across Indonesia and overseas. Moreover, all caretakers from the 
central board to the smallest branch are volunteers, providing their dedication and services, free of charge.

The sizeable membership and political influence of $\mathrm{NU}$ have triggered studies on this largest socio-religious organisation in the world. International scholars from reputable universities have published on a variety of topics such as the discourse of traditionalism (van Bruinessen 1996), politics (Feillard 2013; Feillard 2002; Fealy 2007; Bush 2009; McGregor 2009; Fealy and McGregor 2010; Turmudi 2003), Islamic law (Hosen 2004); civil society (Bush 2002; van Bruinessen and Wajidi 2006), leadership and organisation (Nakamura 1981; van Bruinessen 1991; 2002; Barton 2002; Mietzner 2001), women (Arnez 2010; Feillard 2008), and many other subjects. In addition, Indonesian scholars have also conducted research on this traditional Islamic organisation. Yet much contemporary progress and development has not been covered in prior research. This chapter presents Nahdlatul Ulama (NU) in terms of historical accounts, theology, members and supporters, the ulama $\bar{a}^{3}$, organisational structure, politics, the bahtsul masail forum, and its recent product 'Islam Indonesia'. In order to discover its socio-cultural strategies, this chapter also observes NU's policies related to religious and political issues. It is concluded that 'moderate Islam' is a contested term in contemporary Indonesia, and that while NU's organization has permitted it to represent the interests of a broad swathe of Indonesian Muslims, its lack of authoritative and disciplinary structures has resulted in illiberal attitudes and practices among individual members and participant organisations.

\section{Historical Accounts}

Formally established in 31 January 1926, Nahdlatul Ulama (NU, lit. 'The Revival of 'Ulamā') did not suddenly appear in the history of the Indonesian archipelago or Southeast Asia. Historians pinpoint the initial form of this grassroots movement as appearing in early 1926; however, it can be traced back prior to the twentieth century (Ismail 2011). Its epistemological and ideological traces can even be found as early as the history of Islam in the archipelago. The roles played by $\mathrm{KH}$ Hasyim Asy'ari (hereafter, Mbah Hasyim) and $\mathrm{KH}$ Wahab Chasbullah (hereafter, Mbah Wahab) in the foundation of NU are worthy of discussion. These men are related as guru and student. Mbah Hasyim (1871-1947) suggested to Mbah Wahab (1888-1971) that he continue studying in Mecca after finishing his studies in Tebuireng, Jombang in 1908. In Mecca, Mbah Wahab and his contemporaries including Abdul Halim, Ahmad Sanusi, and Mas Mansur co-founded a Meccan branch of Syarikat Islam (Effendi 2010: 
98). Mbah Wahab was an organiser. In this regard, Mbah Wahab was one of the originators of this traditional organisation, in addition to Mbah Hasyim.

When he returned to Surabaya in 1914, Mbah Wahab established Nahdhatul Wathan (lit. 'The Revival of Homeland') that has been proclaimed as the first religious institution with a nationalistic and moderate character in the archipelago (van Bruinessen 1994: 35). Nahdhatul Wathan grew rapidly and within two years, it already had a madrasa (religious school) with a large two-floor building in Surabaya. Branches spread across East and Central Java including Malang, Gresik, Jombang, Semarang, and other places. Nahdlatul Wathan promoted educational and intellectual development and in 1917, it established Tashwirul Afkar as a medium for Qurānic learning and religious education. Mbah Wahab also founded Syubbanul Wathan (lit. 'Youth of Homeland') and Nahdlatul Tujjar (lit. 'The Revival of Tradesmen') of which members were mostly kyais (Javanese clerics). Mbah Wahab is also said to have established Nahdlatul Fikr (lit. 'The Revival of Thought').

The archipelago had previously witnessed the birth of Muhammadiyah, the movement founded by KH Ahmad Dahlan (1868-1923), in Yogyakarta on 18 November 1912. Muhammadiyah was founded as a puritan, reformist, and modernist socio-religious movement. It aims to purify Islam from local syncretic practices commonly known as "Т ВС" which stands for takhayul (myth, Arab. takayyul), bid'a (religious innovation), and churafat (superstition). It is reformist because KH. Ahmad Dahlan was strongly influenced by the Egyptian reformist Muhammad 'Abduh (d. 1323/1905), and considered the reformation of Islam as a foundational principle. Hence, he advocated ijtihād (individual interpretation of Islam by going back to the Qurān and haditths [hadis in Bahasa]) in contrast to taqlid (following the opinion of the 'ulama $\bar{a}^{3}$ ) as being more important (Ricklefs 1991). Muhammadiyah is the second-largest Islamic movement in Indonesia after $\mathrm{NU}$, and the two organisations have been rivals much of their collective history.

The global politics of Islam also underpinned the birth of NU. There was a heated debate among Muslim organisations in the Archipelago in early 1926 after Ibn Saud took power in Hijaz, establishing the state of Saudi Arabia. Some organisations suggested sending envoys to Mecca to meet King Ibn Saud to advocate for the traditional practices of Muslims. Reformist and modern organisations, however, rejected the idea. As a result, traditionalist Muslims decided to send their own envoy to meet the King and voice their concerns. The envoy (called the 'Hijaz Committee') presented three demands to the King: requesting that he grant freedom of adherence to madhhab (schools of Islamic law) to Muslims in Hijaz; asking that he open access to historical sites connected to the Prophet including the tombs of his daughters; and suggesting that he 
publicise the cost of hajj (pilgrimage). The idea of dispatching the envoy was discussed prior to the birth of $\mathrm{NU}$, but it eventually reached Mecca on 7 May 1928 after NU was founded (Ismail 2011: 257-258).

Observing socio-cultural developments in the homeland of the Indonesian archipelago, where the modernist Muhammadiyah was gaining ground, and a political shift in Mecca where Ibn Saud with his puritanical Wahhäbist form of Islam had gained power, Mbah Wahab strongly suggested that Mbah Hasyim initiate the foundation of an 'ulam $\vec{a}$ ' organisation that would accommodate the interests of religious educational institutions in Java. In addition, several religious practices were challenged by modernist organisations in the archipelago such as al-Irsyad and Muhammadiyah. After heated debates among kyais in Java, Mbah Hasyim initiated the foundation of NU in Surabaya on 31 January 1926 in accordance to 16 Rajab 1438 of the Islamic calendar.

NU is a Sunnī Muslim organisation. In the Indonesian context, 'Sunnī' is equivalent to Ahlus Sunnah wal Jama'ah ('the party of the Sunna', a traditional Arabic expression rendered into Bahasa Indonesia), commonly abbreviated as 'Aswaja'. NU is theologically a middle path (wasatiya, 'moderation') between extreme rationalism and hard-line scripturalism. Following this, the source of Islamic law for NU was not only the Qurān and hadis, but also the power of human reason to understand empirical realities. The idea of the middle path was then conceptualised by NU, following Abū l-Ḥasan al-Ash'arī (874-936) and Abū Manșūr al-Māturīdī (853-944) in kalām and the theological context; following one of the four major madhhabs (Shāfi'ì, Mālikì, Hanafī, or Ḥanbalī) with the majority being Shāfi'i in figh (Islamic law); and following the method of Abū Ḥāmid al-Ghazālī (1058-1111) and Junayd al-Baghdādī (830-910) in tașawwuf (Islamic mysticism). This is clearly evidenced in the Muqaddima (Introduction) of the Qanun Asasi Nahdhatul Ulama, a principal constitution of NU. NU's choices in kaläm, fiqh, and tașawwuf is the theological and local interpretation of imān (faith), islām (submission, rituals), and ịsān (being good) as the common trilogy of being Muslim, in the Indonesian context. The kalām versions of al-Ash'arī and al-Māturīdī teach that NU Muslims must strongly hold their imān. Following one of the four major madhhabs (especially Shāfi 'iyya) is the principal component of isläm for NU. Similarly, orienting their spirituality on the teachings of al-Ghazâlì and al-Baghdādī is the embodiment of ihsān for NU Muslims. This acknowledgement of Șūfi elements marks NU as traditionalist, as opposed to the modernist Muhammadiyah which sought 
to rid Indonesia Islam of Șūi beliefs and practices, among other local and regional variations (Ismail 2011: 253).

After the 1998 reformation and the resulting democratic atmosphere, Indonesia witnessed a stronger presence of transnational Islamic movements such as Wahhābism, Salafism, Hizb ut-Tahrir, and other smaller splinter groups. These movement are all Sunnī or Aswaja, with modernist and puritanical religious orientations. They publicly promote being Sunnī and Aswaja whenever the opportunity arises. This inclination has led to the contestation of the designation 'Aswaja' in Indonesia, as NU is significantly different to these transnational Islamic organisations. Therefore, $\mathrm{NU}$ introduces itself as Ahlus Sunnah wal Jama'ah al-Nahdhiyyah in order to create a distinction from these non-local Islamic organisations. Based on this theological orientation, $\mathrm{NU}$ has been expected to develop Islam on the credentials of those four madhhabs in order to achieve certain short-term and long-term objectives. These include a strong commitment to strengthening associations and unity of practitioners of the four major madhhabs within the community. To support this idea, NU is expected to disseminate Islamic teachings based on the four madhhabs and to select which accredited canons will be used to teach within Ahlus Sunnah wal Jama'ah al-Nahdhiyyah. The above objectives can also be implemented by supporting the construction of new mosques, madrasas (Islamic schools), pesantren (Islamic boarding schools), as well as enhancing its members' wellbeing and improving the quality of life for orphans (Ismail 2011).

The emblem of NU contains symbolism which represents its theology, characters and ideals. Various elements of the emblem reference verses of the Quraan. The globe indicates the place where human beings live and come from on the basis of Q. 20: $55 .{ }^{1}$ This means that $\mathrm{NU}$ aims to maintain the conservation of the Earth for the prosperity of current and future generations. This universal ideal of NU indicates that NU works not only for its members and communities, but also for humankind in general. The Indonesian map on the globe emphasises that NU was born and established in this country. The ropes surrounding the globe means that NU has ideals which tie the population of the Earth in terms of humanity on the basis of Q. $3: 103^{2}$ The number of lines on the rope represents the 99 beautiful names of Allāh. In regards to the globe, the Indonesian

1 Q.S. Taha [20]: 55 says "From the earth We created you, and into it We will return you, and from it We will extract you another time."

2 Q.S. Al 'Imran [3]: 103 says: "And hold firmly to the rope of Allāh all together and do not become divided. And remember the favor of Allāh upon you-when you were enemies and He brought your hearts together and you became, by His favor, brothers. And you were on the edge of a pit of the Fire, and He saved you from it. Thus does Allāh make clear to you His verses that you may be guided. 


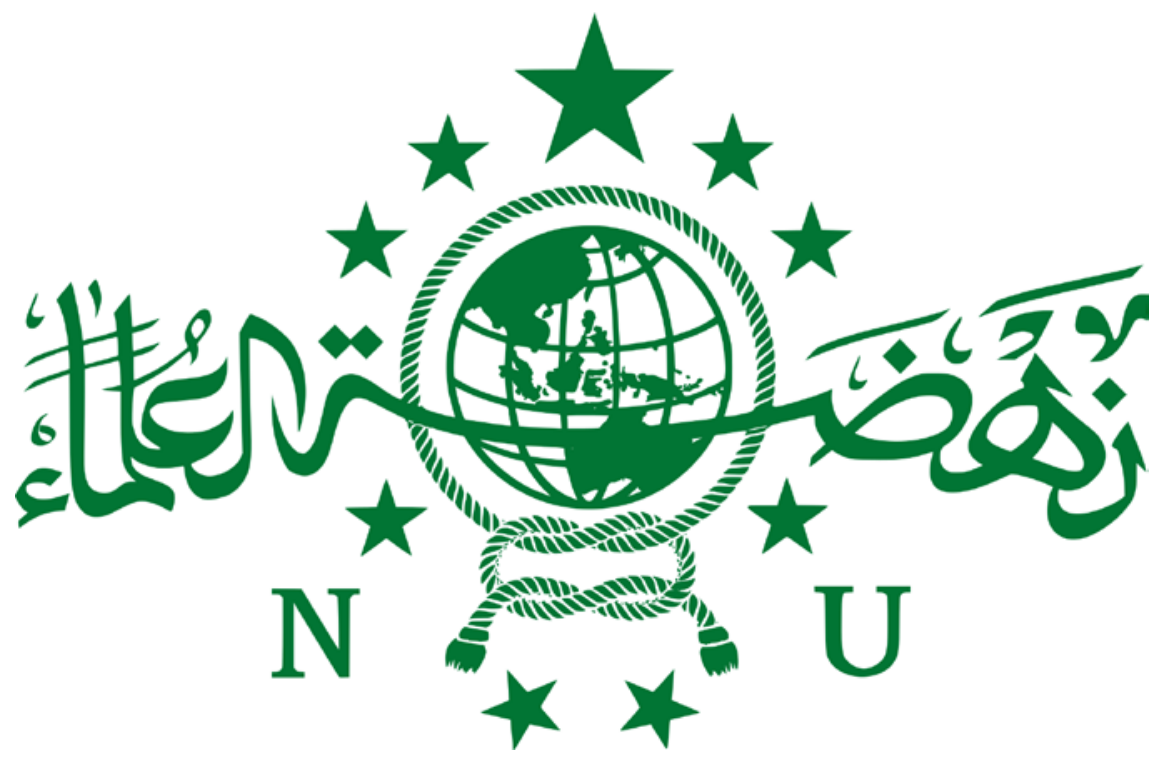

FIGURE 6.1 Emblem of Nahdhatul Ulama PUBLIC DOMAIN

map, and the rope, $\mathrm{NU}$ has innovated three kinds of ties that can unite humankind: ukhuwwa bashariya (human brotherhood), ukhuwwa wataniya (national brotherhood), and ukhuwwa Islamiyya (Islamic brotherhood).

There are nine stars on the emblem signifying great personalities from the history of Islam. The largest star at the top represents the Prophet Muhammad. The four stars on the top right and the left epitomise the four Khulafä' Rāshidūn, the first four ('rightfully guided') caliphs Abū Bakr, 'Umar, 'Uthmān, and 'Alī. The four stars at the lower right and left denote the four great Imāms of madhhabs (schools of Islamic law) Shāfi'ì, Mālikī, Ḥanafì, and Ḥanbalī. The nine stars, hence, strongly claim that $\mathrm{NU}$ follows these great personalities, or in other words, that $\mathrm{NU}$ is faithful to Ahlus Sunnah wal Jama'ah. In the local context, the nine stars also exemplify the nine saints of the archipelago from the fourteenth century, who share the same traditionalist Islamic ideology as NU.

The emblem has two colours: green and white. The green symbolises the fertile and luxuriant land of the archipelago where $\mathrm{NU}$ was born and established. The white is a symbol of chastity and the saintliness of NU's characters. The Arabic writing reads 'Nahdhatul Ulama', while the roman text ' $\mathrm{NU}$ ' is the acronym. The emblem was designed by Kyai Ridwan Abdullah, a contemporary of Mbah Hasyim and Wahab Chasbullah. Ridwan was only given fifteen days to complete the design, but he finished the design in less than the given time. As described above, the emblem embodies the stories, Islamic ideology, theology, ideals, and objectives of $\mathrm{NU}$. 
Founded by kyais in Java, NU traditionally has members consisting of rural populations and santri of pesantren across Indonesia. With ties strongly rooted with kyais in villages across the Archipelago, the rural population are traditionally and culturally followers of NU. They conserve and continue to perform Islamic practices as suggested by local kyais. Practices would include ziyāra (visiting saints' tombs), wasila (intercession), celebrating the mawlid (Prophet's birthday), chanting șalawāt (praises to the Prophet), performing twenty tarāwīh (night prayers during Ramadan), reciting tahlïl (a compilation of specific Qurānic verses, remembrances, and supplications) and reciting narratives of the life of the Prophet by Ja'far al-Barzanjī, sulük or tarīqa practices, and many more. These practices are very common and have become life rituals of the people in rural Indonesia. The key role played by kyais also means that a vast number of members come from traditional, conservative Islamic orientations. They are conservative in terms of conserving Islamic traditions and practices based on strong attachment to al-turāth or tradition as recorded in hundreds of Arabic manuals commonly learned in pesantren. They are conservative as they keep practicing what the Javanese saints had designed centuries ago as the best form of the amalgamation of Islam and local culture (Barton 1997: 324).

The current number of pesantren and similar schools across Indonesia is approximately 30,000, with santri (pesantren students) and alumni constituting the cultural followers of this traditionalist Muslim organisation (Azzahra 2020 ). Not only do they perform the practices, they also know and understand and are able to elaborate the theological reasoning behind the practices. As santri of pesantren, they are equipped with strongly rooted "tool knowledge" such as the knowledge of Arabic including nahww (grammar), șarf (morphology), balägha (rhetoric), and adab (literature). For these tasks, it is an important within traditional learning that they memorise manuals of Arabic grammar, from brief texts such as Matn al-Ajrummiyah or al-Imriti, to the extensive texts like Alfyya Ibn Malik, which consists of more than a thousand Arabic pieces of poetry. This is in addition to their obligation to memorise the Qurān and hadis.

Furthermore, santri are traditionally defined as those who reside in the pesantren, and who follow and obey the kyai (Fealy and Bush 2014: 541). Both kyai and santri enjoy a special relationship of guru and pupil, of supervisor and supervisee, or that of parent and children. The high reverence of santri toward their kyai is indicated with hand kissing during the greeting handshake, listening and following advice, physical loyalty, and the taking of sanad (chain of 
knowledge transmission). The reverence is not limited to the students' time in the pesantren, but throughout the person's lifetime. Pesantren have been hermitages and retreats for pupils where they train as Indonesian Muslims for six to nine years. Afterward, they often return to their villages and establish new pesantren which follow the educational system and practices of the pesantren from which they graduated (Hefner 2009; Azra, Afrianty, and Hefner 2007). This practice disseminates the traditionalist Muslim education and values in Indonesia.

NU followers have also been identified as the 'sarungan' people characterised by the cloth or sarongs they always commonly wear. Sarongs are worn in pesantren, as well as for other socio-religious occasions outside pesantren. Sarongs, batik shirts or koko with black peci (hats) on the head are a common fashion style for Indonesian men on important occasions. When Abdurrahman Wahid ('Gus Dur') was the President of Indonesia, he was very often visited by kyais from pesantren, who arrived at the presidential palace in Jakarta wearing this attire, a sight that was rarely seen in the capital, Jakarta.

As described above, sanad as a chain of knowledge transmission, is one of the foremost qualities of NU. Possessing a sanad is considered an object of pride for NU Muslims as they participate in a direct line of authoritative knowledge and ' ulam $\bar{a}$. Some of them simply memorise the full chain. Some write down the sanad in their personal customised diaries or books. Some even draw the sanad beautifully in a chart and display it on the wall of their house. As there are a vast number of sanad among 'ulamä' within $\mathrm{NU}$, the current chairperson of NU, KH. Said Agil Siradj will be used as an example to demonstrate the continuous sanad or chain of transmission of religious knowledge back to the Prophet Muhammad, in the chart below. The chart shows at least twenty-eight chain links of transmission of religious knowledge. They are all important names, but the most significant names and related to the discussion of $\mathrm{NU}$ are given in yellow. The chart shows that the current chairperson of NU, Said Agil Siradj (28) has sanad to Mbah Hasyim/Hasyim Asy'ari (25), the founder of NU, to Abū Ḥāmid al-Ghazālī (14), an NU reference in taṣawwuf, then to Abū al-Ḥasan al-Ash'arī (10, an NU reference in kalām, to the Prophet Muhammad (1). Some scholars even expand on this by suggesting that the Prophet Muhammad received the knowledge from Jibrill, the Angel of Revelation, who received knowledge from Allāh. 


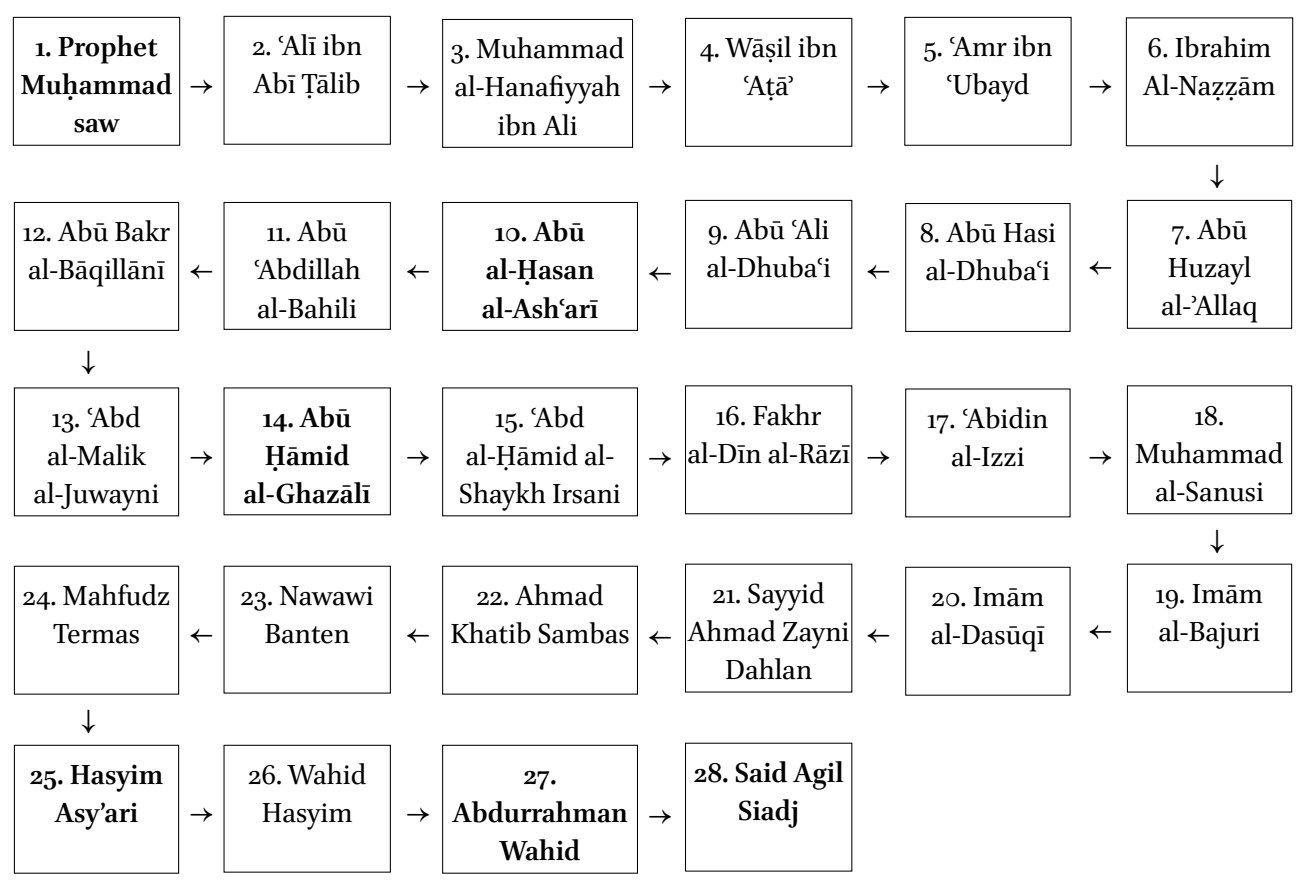

FIGURE 6.2 Sanad of NU's 'Ulama $\overline{\text { ' }}$

The above example is simply written as a linear form of sanad, where there is only one 'alim or Muslim scholar in each chain. Realistically, however, there are a number of other names in each chain which continue the same chain eye in different levels or generations. For instance, Mbah Hasyim/Hasyim Asy'ari (25) learned and received sanad of knowledge from Mahfudz Termas (24), and at this same level, also from Arsyad al-Banjari, Kholil Bangkalan, 'Abdul Shomad Palembang, and many more. These four 'ulamä' learned and took sanad from Nawawi Banten (23). Similarly, a number of 'ulam $\bar{a}^{\prime}$ might be present in each level of the example of sanad above.

There is indeed a list of sanad of NU's 'ulamä' that involve al-Māturīdī, an NU reference in kalām, or Imām al-Shāfi'ì, an NU reference in fiqgh, or al-Baghdādī, an NU reference in tașawwuf. Moreover, there are other special sanads based on particular kitab kuning (lit. 'yellow books', referring to Arabic books), canons, or manuals that are learned from generation to generation of 'ulama $\vec{a}$ and santri in pesantren all over Indonesia. For example, it is easy to find sanad of NU's 'ulamä' for, for example, the șahịh of Imām al-Bukhārī, the number one canon of hadis. This means that the sanad from Imām al-Bukhārī, to his students which continued to other students, and was passed along to the current 
NU's 'ulam $\bar{a}$ ' and santri, is definitely present. Similarly, this is also the case for millions of sanads for other kitab kuning and Arabic manuals traditionally read and learned in the pesantren of $\mathrm{NU}$ across Indonesia.

Pengurus Besar Nahdhatul Ulama (PBNU) is the leadership system and organisational structure covering the Mustasyar (Advisory Board), Syuriyah (Supreme Council), A'wan (Expert Board), and the Tanfidziyah (Executive Board). The highest body within this organisation is the Syuriyah or Supreme Council of which the leader is named Ra'is 'Am, the vice is Naib Rais, and the secretary is Katib Syuriyah. The Tanfidziyah or Executive Board is led by Ketua Umum (general chairperson) and the Secretary General. The Rais 'Am of the Syuriyah Council and the Ketua Umum of Tanfidziyah Council are elected every five years through Muktamar. Another body, which provides advice to both councils, is the Mustasyar consisting of senior ' $u l a m \vec{a}^{\prime}$ and members.

Several lembaga or institutions within PBNU are formed in order to optimise the running of the organisation. The lembaga work as departmental institutions and serve as policy implementers in dealing with certain community groups or any groups that require special treatment. PBNU also supervises several lajnah or institutions dealing with key programmes within NU. In addition, PBNU also have several semi-autonomous organisations serving particular community religious interests. The lembaga include Lembaga Dakwah Nahdhatul Ulama (LDNU, for Islamic propagation), Lembaga Pendidikan Ma'arif Nahdhatul Ulama (LP Ma'arif NU, for education), Lembaga Pelayanan Kesehatan Nahdlatul Ulama (LPK-NU, for health services), Lembaga Perekonomian Nahdlatul Ulama (LP-NU, for economics), Lembaga Pengembangan Pertanian Nahdlatul Ulama (LPP-NU, for agriculture), Rabithah Ma'ahid Islamiyah Nahdlatul Ulama (R MI-NU, for pesantren or Islamic boarding schools). Lembaga Kemaslahatan Keluarga Nahdlatul Ulama (LK K-NU for family), Lembaga Takmir Masjid Nahdlatul Ulama (LTM-NU, for mosque welfare), Lembaga Kajian dan Pengembangan Sumberdaya Manusia Nahdlatul Ulama (LAK PESDAM-NU, for human resources), Lembaga Penyuluhan dan Bantuan Hukum Nahdlatul Ulama (LPBH-NU, for legal issues), Lembaga Kesehatan Nahdlatul Ulama (LK-NU, for health), Lembaga Badan Halal Nahdlatul Ulama (LBHNU, for halal), and Sarikat Buruh Muslimin Indonesia (sARBumusI, for workers). 
PBNU also consists of several lajnah or boards, including Lajnah Bahtsul Masail Nahdlatul Ulama (LBM-NU, for religious Islamic matters), Lajnah Falakiyah Nahdlatul Ulama (LF-NU, for celestial spheres), Lajnah Ta'lif wan Nasyr Nahdlatul Ulama (LTN-NU, for publications), Lajnah Auqaf Nahdlatul Ulama (LA-NU, for endowments), Lajnah Zakat, Infaq, dan Shadaqah Nahdlatul Ulama (LAZIS-NU, for charity). Additionally, PBNU maintains autonomous boards including Jam'iyyah Ahli Thariqah Al-Mu'tabarah An-Nahdliyah (JATMAN, for Șüfi groups), Muslimat Nahdlatul Ulama (Muslimat NU, for women), Gerakan Pemuda Ansor Nahdlatul Ulama (GP Ansor NU, for youth), Fatayat Nahdlatul Ulama (Fatayat NU, for female youth), Keluarga Mahasiswa Nahdlatul Ulama (KMNU, for university students), Ikatan Pelajar Nahdlatul Ulama (IPNU, for male disciples), Ikatan Pelajar Putri Nahdlatul Ulama (IPPNU, for female disciples), Ikatan Sarjana Nahdlatul Ulama (ISNU, for graduates), Ikatan Pencak Silat Nahdlatul Ulama Pagar Nusa (IPSNU Pagar Nusa, for martial arts), Jami'iyyatul Qurro wal Huffadz Nahdlatul Ulama (JQH NU, for Qurānic reciters and memorisers), and Persatuan Guru Nahdlatul Ulama (PERGUNU, for teachers).

NU boards extend from PBNU as the central board to the smallest regional boards. The board levels in sequences include PBNU, Pengurus Wilayah Nahdhatul Ulama (PWNU, for the provinciallevel), Pengurus Cabang Nahdhatul Ulama (PCNU, for kabupaten/kota or the district level), Majelis Wakil Cabang Nahdhatul Ulama (MWCNU, for kecamatan or the sub-district level), Pengurus Ranting Nahdhatul Ulama (PRNU, for kelurahan/desa or sub-sub-district level), and Pengurus Anak Ranting Nahdhatul Ulama (PARNU, as the smallest regional board). NU also has special branches overseas called Pengurus Cabang Istimewa Nahdhatul Ulama (PCI-NU). NU is a loosely-organised movement, in that the kyais and pesantren are the core personnel and institutions, and the "central and regional boards had limited authority over, or desire to dictate to, locally influenced kyai" (Fealy and Bush 2014: 542).

Since it was founded in 1926, NU has been primarily a socio-religious organisation. The Qanun Asasi of NU has no single point which explicitly intersects with politics. However, the strong figh orientation of $\mathrm{NU}$ in its Islamic creeds and rituals has forced $\mathrm{NU}$ to discuss politics. This is normal as canons of figh always contained politics-related discourses such as imāma (Islamic leadership), qaḍä' (judge-related topics), bughāt (rebellion), hudūd wa ta'zirat (punishment and retribution), qisas (requitals), and al-walä $w a-l-b a r a \bar{a}^{\prime}$ (loyalty 
and disavowal). All of these figh discourses initially envisage the presence of Islamic power in politics. With very large numbers of traditional followers, especially in Java, this enables $\mathrm{NU}$ to be present as a political power in the archipelago (Ismail 2011).

NU initially intersected with politics when it issued a decree on land defence in 1935. It stated that the Archipelago is a land of Muslims. On another occasion, NU also stated that supporting Japan in the Pacific War was not wājib nor an obligation for Muslims, or for people generally living in the archipelago. In the 1938 Muktamar in Menes, there was a proposal that NU should place its representatives in the Volksraad (the People's Council) that was initially formed in 1916 by the Dutch Administration in the East Indies (Indonesia). The majority of the Muktamar participants rejected the idea and wanted to keep $\mathrm{NU}$ as a socio-religious organisation.

Despite classical competing rivalry between NU and Muhammadiyah, both Islamic organisations established the Majelis Islam A'laa Indonesia (MIAI, the Supreme Islamic Council of Indonesia) in 1937 in order to inaugurate an umbrella or federal organisation for all Islamic groups in the archipelago (Ismail 2011: 271). It united and coordinated the voice of Muslims in the Archipelago to argue against Dutch policies, such as the marriage ordinance and military service for Muslims. The Japanese occupation changed the political atmosphere and sponsored the foundation of Masyumi or Majelis Syura Muslimin Indonesia (Consultative Council of Indonesian Muslims) in 1945 when Mbah Hasyim became the national chairperson.

The core role of NU in Masyumi caused NU to start becoming a political movement. After experiencing severe disadvantage while within Masyumi, $\mathrm{NU}$ left the council, as decided in the PBNU decree dated 5/6 April 1952 (Fealy and Bush 2014: 542). The decision was then brought to the nineteenth century Muktamar from 28 April-1 May $195^{2}$ in Palembang. The Muktamar supported the move and recommended that NU become a political party. NU then founded Liga Muslimin Indonesia (LMI, the Indonesian Muslims League) on 30 August 1952, with Persatuan Tarbiyah Indonesia (Perti, Indonesian Tarbiyah United), Partai Syarikat Islam Indonesia (PSII, Islamic Association Party of Indonesia), South Sulawesi-based Darud Da'wa wal Irsyad (DDI) and Persyarikatan Tionghoa Islam Indonesia (the Indonesian Tionghoa Muslim Association). In parliament, seven NU members left the Masyumi faction and formed an independent bloc (Feith 2007: 233-235).

During the process of withdrawing from Masyumi and becoming a political party, the NU Party only had a short time to prepare for the 1955 election. The NU Party eventually took part in the 1955 election and won 45 seats $(18.4 \%$ votes) in the DPR, ranking third behind the PNI (Indonesian National 
Party) and Masyumi, each of which held 57 seats. In the following election for Konstituante (Constitutional Assembly), the NU Party won 91 seats (Friend 2003: 51). Under the New Order policy in 1973, the NU Party was then forcibly fused with Partai Persatuan Pembangunan (PPP, United Development Party), which won the second-largest number of seats in the 1977 and 1982 elections. Due to dissatisfaction and lack of influence, Abdurrahman Wahid, the Chairman of NU, withdrew from PPP, causing a decline of votes for PPP, from $28 \%$ in 1982 to $16 \%$ in the 1987 election (Ricklefs 1991: 276). Since then, NU has been a socio-religious organisation.

\section{Bahtsul Masail}

As described above, NU has a lembaga or board, which is in charge of answering religious Islamic matters arising within Muslim societies in Indonesia. In the past, the discussion of contemporary issues was conducted in a forum called Lailatul Ijtima 'Nahdatul Oelama or LINo (lit. 'evening of gathering of $\mathrm{NU}$ '). This was an intellectual arena for kyais in order to grant legal standings of religious matters. Currently, after the institutionalisation of Bahtsul Masail, the LINO uses another format. In many regional meetings, the LINO has been set up as a regular meeting for learning, where a kyai presents and discusses an Arabic work in front of the board and members of PWNU (regional board).

Lembaga Bahtsul Masail-Nahdhatul Ulama (LBM-NU, henceforth LBM) is a creative and important scheme of ïtihäd or fatwā production (Laffan 2005). It is significant and inventive for at least two reasons. First, Muslims outside Arab countries used to seek advice and fatwa from 'ulam $\bar{a}$ ' in the Middle East on religious issues in their home countries. A famous work entitled Muhimmat al-Nafa'is fi Bayan As'ilat al-Hadith, a nineteenth century compilation of questions and fatwa $\bar{a}$, records questions from Muslims in the archipelago, and fatwa from Middle Eastern countries and regions, especially Mecca and Cairo (Kaptein 1997; Hosen 2004). LBM has successfully ended this practice by offering answers to religious Islamic matters. Second, before the presence of LBM, Islamic authorities including individual alim delivered their independent and individual legal opinions, or ijtihād, or fatwa $\bar{a}$ pertaining to various religious issues facing Muslim communities. LBM has taken a step forward by introducing collective ïjtihād or ïtihādjamā $\bar{\imath}$ (Hosen 2004).

LBM consists of senior and junior ulama $\vec{a}^{3}$ or senior santri who are considered knowledgeable and authoritative in Islamic matters. Their authority includes a mastering of Arabic grammar, tafsir and hadis knowledge, Islamic law, Islamic history and other supporting knowledge. More particularly, they 
must ideally be faqih al-nafs (talented in Islamic legal matters), experienced in figh and its application, and able to present the $f i q h$ and its details. If this is impossible to be observed individually, a collective feature of these authorities would be an option. These are the main features of an LBM.

LBMS are present in NU boards either in central (PBNU) or regional (PWNU) areas. The issues or questions must be individually identified as local, regional, or national jurisdictions. LBM in the regional boards, for example, discuss all questions and issues from that particular region. When it is considered national, it must be referred to the LBM central board. Similarly, when it is a local issue, the regional board will discuss and issue the decision. All discussions must be conducted in a forum called Bahtsul Masail. The main task of LBM is to analyse actual cases that have not been found in kitab kuning and figh manuals. Hence, their task is ilhaq al-masail bi nazhairi-ha: using what is relevant or analogous in kitab kuning and figh manuals to assess contemporary matters. If the case has been discussed and found in figh manuals, LBM simply demonstrates what options are available. However, if there is a new case, their task extends to ilhaq al-masail bi nazhairi-ha. For these reasons, LBM is generally divided into three issue categories: wāqi iyya (actual cases), mawdu'iyya (thematic cases), and qānūniyya (legal category).

From here, it is clear that the task of LBM is not to extract the law or istinbat al-ahkam directly from the Qurān and hadis as two primary sources of Islamic law, due to their particular limits (Mahfudz 2003: 24). LBM instead applies ilhaq al-masail bi nazhairi-ha, namely linking new issues dynamically to the similar ones available in any kitab kuning or figh manuals. This demands high levels of skill for the participants of Bahtsul Masail in the field of figh. Due to its important status, Syuriyah is the NU board, which is responsible for organising the Bahtsul Masail (Hosen 2004). The Syuriyah Board organises the Bahtsul Masail at least twice every five years; once in the five yearly NU Muktamar, and once in the Musyawarah Nasional alim Ulama NU (Zahro 2004: 26). The issues discussed in Bahtsul Masail are actual matters arising within Muslim communities in Indonesia. Issues can also be raised by the PBNU which might consider particular matters important. PBNU then distributes the materials, including questions and issues to participants of the Bahtsul Masail, including 'ulam $\bar{a}$, intellectuals, and any LBM members who are trusted. Before coming into the Bahtsul Masail, they would read them and prepare their answers. The PBNU then discusses issues in detail and makes decisions.

When providing decisions to issues being discussed, the Bahtsul Masail usually applies a number of methods including qawli (literal), ilhaqi (comparative method), and manhaji (by methodology). The qawli method enables participants to have direct quotations from acknowledged figh manuals and books, 
especially from the four madhhabs. The ilhaqi method envisages the making of law by developing analogies between unlisted issues and similar ones available in the figh books and manuals. Meanwhile, the manhaji method requires deep research and follows the method of istinbat al-ahkam of the four madhhabs, for problems that are unresolved by the qawli and ilhaqi methods. This explanation could be broken down into at least three steps or processes. First, when new matters are found in the authoritative figh manuals or books this could be considered a decision. Second, following the first step: if there are differing opinions from 'ulam $\bar{a}$, they apply taqrír jama $\bar{a} \bar{\imath}$ (to make a decision of one strong opinion). Third, when these matters are not listed in the fiqh manuals, they apply ilhaq al-masail bi nazhariha.

\section{Indonesian Islam}

One of the most important products of NU is so-called 'Indonesian Islam'. The intention is not to create a negative distinction of Indonesian Islam from the rest of the Muslim world. Rather it is to demonstrate khasa'is or the special qualities of Indonesian Islam, and to accentuate the cultural tastes and experiences of Indonesian Islam. The theology remains the same as that in other Muslim territories, especially the Sunnī world. There is no space within Indonesian Islam to change the principles of Islam such as arkän al-islam (the Five Pillars of Islam) and arkān al-imañn (the Six Pillars of Faith). This is to highlight that the fact that Indonesian Islam shares its theology with the rest of the Muslim world (Ismail 2011: 249). Behind the concept of Indonesian Islam is an appreciation of localities, including the ways of life, cultures, traditions, and practices that are not in contrast to Islamic principles. This is based on one concept of figh and ușül al-fiqh, al-'ada or al-'urf muhakkama, that localities can be considered a source of law under the Qurān and hadis. In this regard, $\mathrm{NU}$ accommodates local cultures and practices as long as they do not harm the fundamental principles of Islam. One of the most visible demonstrations of this idea are the local customs of wearing sarongs, peci (Indonesian black hats), batik (traditionally decorated Indonesian shirts) or koko (Shanghai-style shirts) during prayers.

Islam in Indonesia has often almost escaped attention even though it constitutes the largest majority Muslim population; the geographical position of Indonesia is at the eastern end of the Muslim world, and it was historically considered to have a low profile in the Muslim world's intellectual, economic, social, and global political arenas. These factors triggered the neglect of Indonesian Islam by various international analysts. In addition, the absence of 
Indonesia as a participant in any of the Muslim world contestations is another reason why Indonesia has been neglected. The uniqueness of Indonesia that has been most visible, compared to other parts of the Muslim world, and which Samuel Huntington insisted that the clash of civilisations neglected, is the inclination to accept modernity and democracy, to voice pluralism and religious tolerance, and to accentuate the gracious and the merciful sides of God (Inoguchi 2012). The cultural movements which have been dominating the discourses of Indonesian Islam since the course of the twentieth century, have become the main indicators. In addition, significant actions and movements of neo-modernist Islam in Indonesia, have become another trigger for the promotion of Indonesian Islam. These cultural and religious movements are the consequences of a unique approach to understanding Islamic texts and local cultures, traditions, and practices. The approach has a dual role; to heighten social ethics and individual piety, while at the same time, to refrain from highlighting unnecessary differences in the Muslim world.

In this regard, Abdurrahman Wahid (1940-2009), three-term chairperson of NU (1984-1999) and the fourth President of Indonesia, has been regarded as the foremost pioneer of neo-modernism of Islam in Indonesia (Barton 1997). In the wake of the Iranian revolution and its influence on Indonesian youth, Abdurrahman Wahid (Gus Dur) rejected Western analysts who believe that Middle Eastern fundamentalism had a strong and deep influence on Indonesian students studying in the Middle Eastern universities. Abdurrahman argued that Islam and Arab culture are two different things. In addition, Abdurrahman successfully highlighted the traditions of Islamic pluralism in Indonesia through his writings which emphasise theological, philological and historical approaches in explaining Indonesian Islam. According to him, the development of Islamic cultures is the product of acculturation between Islamic core values and cultural qualities of archipelagic Indonesia. This is the context when he argues that the harmonious life of religions in Indonesia provides strong traditional roots for modern pluralism (Barton 1997:342).

Following this idea, there is a strong argument that Islam should be considered on two levels, namely on the theological and cultural levels. In terms of theology, Islam is a universal religion which works harmoniously in any given time and place. Despite different opinions and understanding of 'ulama', Islam is one and is dedicated and oriented toward one identical aim, which is to worship and affirm the oneness of Allāh. At this level, NU is the same as other Sunnī groups and movements (Ismail 2011: 249). NU, however, would be more conservative in religious rituals and worship than some other groups and streams, as NU holds strongly to kitab kuning as textual interpretations of the Qur'ān and hadis. On another similar level, Islam is a manifestation and 
expression of religiosity that can be married to local cultures and practices. $\mathrm{NU}$ generally believes that anything that is not regulated by Islam is halal or permissible until one or more texts in the Qur'ān and hadis have been identified which restrict it. This completely differs from the Salafi groups, for example, who consider that everything is forbidden until there are one or more texts of the Qur'an and hadis allowing it. On the basis of that principle, and with the support of another principle that habit or culture is a potential source of law, $\mathrm{NU}$ has been in the avant garde by advocating for local practices that are not in contradiction to the principles of Islam.

NU could be even more "radical" in promoting localities. Gus Dur is famous for his slogan Pribumisasi Islam or "indigenisation of Islam." Abdurrahman Wahid's generation and those following within NU have been strong supporters of this idea. There has been a common understanding that Islam must be friendly to local practices. For NU, the indigenisation of Islam is necessary, to avoid the polarisation of religion (Islam) and culture. In this regard, indigenisation is not syncretism as it simply considers localities within the process of the application of Islamic teachings. Neither does it neglect Islamic norms for cultural ones. The idea is that Islam accommodates localities by making use of the interstices and opportunities provided by Islam. In this regard, NU plays hard with the significant roles of the principles of fiqh and uṣul al-figh in accommodating localities. In addition, $\mathrm{NU}$ believes that indigenisation in any part of the Muslim world is an integral part of the history of Islam.

The important roles of NU-based Ministers of Religious Affairs, as well as other non-NU Ministers, are also effective in the harmonious life of religions in Indonesia. The Ministry of Religious Affairs (MoRA) has become a main actor of these cultural movements by attaching them to state policies. In this regard, the position of the Ministers of Religious Affairs is becoming more significant in playing their inter-related roles. They are expected to become the primary speaker for the government, and, at the same time, the defender of Muslim interests in promoting harmonious life in Indonesia. They are in charge of and responsible for the harmonious life and cooperation between various religious communities in Indonesia. Similarly, other non-NU-based Ministers of Religious Affairs have played the same significant role. Nevertheless, the close attachment of religions to the state might result in a more dominant position of the state vis-à-vis the people (Muslims).

The MoRA has also been supporting Indonesian Muslim intellectuals to develop their Islamic thoughts by providing scholarships and funding to closely interact with the contemporary academic communities globally. It has sent many lecturers and students to both Middle Eastern and Western universities. In this regard, Muslim intellectuals have enriched their knowledge 
and horizons in social sciences and humanities, and in turn supported their traditional Islamic studies to develop progressive thoughts. They are skilful in interplaying the truth claims within social sciences and humanities and within Islam. As a result, traditionally NU-based intellectuals have produced progressive thoughts and movements. They are authoritative in speaking and writing on Islam on the basis of kitab kuning, yet at they are fluent in quoting and making use any use of sociological, historical, anthropological approaches and theories. The interdisciplinary expertise developed by NU scholarships, as well as non-NU ones, have been contributively catalyst to the development of friendly and tolerant Islam in Indonesia. Woodward (1996) considers this development as a "new paradigm" in the contemporary history of Islam. He believes that Indonesian Islam is unique and different from historical Islam in other Muslim regions.

Through the idea of indigenisation of Islam, NU rejects Arabisation in many aspects of cultural Muslims' life. The text of the Qur'ān, as well as those recited in prayers, will always remain in Arabic, but the contextualisation of Islamic teachings from the Qurân and hadis can be actualised according to the locality. NU Muslims could possibly be more fluent in Arabic that any other groups in Indonesia, as Arabic is one of the core subjects in NU pesantrens across Indonesia. The ultimate point of this accommodation is to emphasise that Muslims living anywhere. and at any time, could potentially become authentic Muslims while still belonging simultaneously to their own culture. When it is extended to the nation-state context, it can be said that Muslims living in Indonesia could potentially become authentic Muslims while also being genuine Indonesians. This should not affect their loyalty as Muslims and as Indonesian citizens at the same time. Likewise, by applying this approach, Muslims living in Europe, America. Australia, and other Muslim minority countries, could realistically belong to their countries of citizenship, while simultaneously living as authentic Muslims. They share the same opportunities to be authentic Muslims as Muslims living in Saudi Arabia.

As described above, NU began from robust Arabic and Islamic materials learned and scrutinised in pesantrens in Indonesia over time. NU possesses a vigorous tradition which interplays with Islamic texts. This means that NU is fundamentally traditional in its approach to both texts and practices (Aspinall 2010: 121). Based on this fact, some people misunderstand NU to be backward in thought, opportunistic in politics, and syncretic in religiosity (Aspinall 2010: 
133). In contrast, religious traditionalism has enabled $\mathrm{NU}$ to be a progressive religious organisation. The self-consciousness traditionalism has even allowed $\mathrm{NU}$ to become the most prepared Islamic group to face modernity and changes. Criticising an established Western view that religious traditionalism precludes progressivity, Nakamura (1981) argues that NU's traditionalism is not in contrast vis-à-vis progressivism in politics.

Nevertheless, the history of Islam in Indonesia has not been linear. There have been a number of violent actions conducted in the name of Islam. The development of the Right and hardliners seems to have found support on the ground. This could influence the common claim and perception of a friendly and tolerant Islam in Indonesia. For example, the loose organisational structure of $\mathrm{NU}$ has in practice meant that it is unable to discipline grassroots clerics who express illiberal sentiments, for example, declaring the Shīa and Ahmadī minorities to be heretics, and violently persecuting them (Arifianto 2017: 241). Therefore, there is a continuous need to promote what $\mathrm{NU}$ has actually constituted so far.

New generations of NU are currently building on Gus Dur's idea of indigenisation of Islam (Effendi 2008). Since 2000, this has created a stream within NU called Post-traditional Islam. The new stream envisages a critical evaluation of tradition (al-așa la $)$ with the traditional values and norms (al-turāth) themselves. Post-traditional Islam has made tradition its fundamental epistemology to transform into a new tradition strongly rooted in the old tradition with a progressive ethos. Through objectification and rationalisation, it deconstructs the tradition so the new one will be more compatible with present-ness (Baso 200o; Rumadi 2015). This differs from modernism, which neglects or even rejects tradition in order to arrive in modernity.

This traditionalism-based socio-religious movement with progressive character has also inspired and stimulated women's movement within this framework. Interestingly, with modern gender awareness that they had absorbed, NU women has experienced progressive development based on traditionalism. They have revitalised the horizons of Islamic traditionalism by promoting open discussion of interpretive tradition from tafsir (the interpretation of the Qur'ān) and hadis. In addition, the heavy-duty combinations of authoritative 'ulam $\bar{a}$, pesantren education, and kitab kuning that have been learned by santriwati (female santri) have planted, grown, and harvested the construction of female Islamic authority (Saenong 2016; 2019). Rahima, Fahmina, and 'Alimat are at least some Non-Governmental Organisations (NGO) and Civil Society Organisations (CSO) with national and global level movement and reputation that have been inspired and born from the womb of NU. They have been working hand-in-hand to establish the Islamic authority of 'alimat (female 'ulama'). 
The three cso have even conducted the first international congress of women's 'ulam $\bar{a}$ ' in 2017 that has been a cutting-edge progress of women movement, as well as women's Islamic authority in classical and modern Islamic studies (Saenong 2019). It is concluded that while 'moderate Islam' is a contested term in twenty-first century Indonesia, $\mathrm{NU}$ has been able to represent the interests of a large number of different social groupings of Indonesian Muslims, though over time it has lost specifically political power and influence since the presidency of Abdurrahman Wahid ended in 2001 (Fealy and Bush 2014).

\section{Acknowledgment}

I'm extremely thankful to Afzal Upal and Carole Cusack, Venetia Robertson, and Eva Nisa and reviewers for their valuable comments. I'm responsible for any mistakes in this paper.

\section{References}

Arifianto, A.R. 2017. "Practicing What It Preaches? Understanding the Contradictions between Pluralist Theology and Religious Intolerance within Indonesia's Nahdlatul Ulama." Al-Jami'ah Journal of Islamic Studies. 55:2, 241-264.

Arnez, M. 2010. "Empowering Women through Islam: Fatayat NU between Tradition and Change." Journal of Islamic Studies. 21:1, 59-88.

Aspinall, E. 2020. "Semi-Opponents in Power: The Abdurrahman Wahid and Megawati Soekarnoputri Presidencies." In E. Aspinall and G. Fealy eds, Soeharto's New Order and its Legacy: Essays in Honour of Harold Crouch. Canberra: Australian National University Press, 119-134.

Azra, A., D. Afrianty, and R.W. Hefner. 2007. "Pesantren and Madrasa: Muslim Schools and National Ideals in Indonesia." In R.W. Hefner and M.Q. Zaman eds, Schooling Islam. The Culture and Politics of Modern Muslim Education. Princeton, NJ: Princeton University Press, $172-198$.

Azzahra, N.A. 2020. Effects of the Pesantren Law on Indonesia's Education System: A Projection. Jakarta: Centre for Indonesian Policy Studies.

Barton, G. 1997. "Indonesia's Nurcholish Madjid and Abdurrahman Wahid as intellectual Ulama: The Meeting of Islamic traditionalism and modernism in neomodernist thought." Islam and Christian-Muslim Relations. 8:3, 323-350.

Barton, G. 2002. Gus Dur: The Authorized Biography of Abdurrahman Wahid. Jakarta: Equinox Publishing.

Baso, A. 20oo. "Pengantar." In M.A. al-Jabiri, Post-tradisionalisme Islam. Yogyakarta: LKiS. 
Bruinessen, M. van. 2002. "Back to Situbondo? Nahdlatul Ulama Attitudes towards Abdurrahman Wahid's Presidency and His Fall." In H. Nordholt and I. Abdullah eds, Indonesia in Search of Transition. Yogyakarta: Pustaka Pelajar, 15-46.

Bruinessen, M. van. 1996. "Traditions for the Future: The Reconstruction of Traditionalist Discourse within NU." In G. Barton and G. Fealy eds, Nahdlatul Ulama, Traditional Islam and Modernity in Indonesia. Clayton, viC: Monash Asia Institute, 163-189.

Bruinessen, M. van. 1991. "The 28th Congress of the Nahdlatul Ulama: Power Struggle and Social Concerns." Archipel. 41, 185-200.

Bruinessen, M. van, and F. Wajidi. 20o6. "Syu'un Ijtima'iyah and the Kiai Rakyat: Traditionalist Islam, Civil Society, and Social Concerns." In H. Nordholt, ed., Indonesian Transitions. Yogyakarta: Pustaka Pelajar, 205-248.

Bush, R. 2009. Nahdlatul Ulama and the Struggle for Power within Islam and Politics in Indonesia. Singapore: ISEAS.

Bush, R. 2002. Islam and Civil Society in Indonesia: The Case of Nahdlatul Ulama. Doctoral Dissertation. University of Washington.

Effendi, D. 2008. A Renewal without Breaking Tradition: The Emergence of a New Discourse in Indonesia's Nahdlatul Ulama during the Abdurrahman Wahid Era. Yogyakarta: Interfidei.

Fealy, G. 2007. "The Political Contingency of Reform-mindedness in Indonesia's Nahdhatul Ulama: Interest, Politics, and Khittah." In A. Reid and M. Gilsenan eds, Islamic Legitimacy in a Plural Asia. London and New York: Routledge, 154-166.

Fealy, G. and E.K. McGregor. 2010. "Nahdlatul Ulama and the Killings of 1965-66: Religion, Politics, and Remembrance." Indonesia. 89, 37-6o.

Fealy, G. and R. Bush. 2014. "The Political Decline of Traditional Ulama in Indonesia: The State, Umma and Nahdlatul Ulama." Asian Journal of Social Science. 42:5, 536-56o.

Feillard, A. 2013. "Nahdlatul Ulama in Indonesia." In J. Esposito and E. Shahin eds, The Oxford Handbook of Islam and Politics. Oxford: Oxford University Press.

Feillard, A. 2008. "Islamisme et démocratie en Indonésie, quand la tradition se rapproche de la cause des femmes." Archipel. 75, 199-230.

Feillard, A. 2002. "Indonesian Traditionalist Islam's Troubled Experience with Democracy (1999-2001)." Archipel. 64, 117-144.

Feith, H. 2007. The Decline of Constitutional Democracy in Indonesia. Jakarta, Kuala Lumpur and Singapore: Equinox Publishing (Asia).

Hefner, R.W. 20o9. Making Modern Muslims, the Politics of Islamic Education in Southeast Asia. Honolulu: University of Hawai'i Press.

Hosen, N. 2004. "Nahdlatul Ulama and Collective Ijtihad." New Zealand Journal of Asian Studies. 6:1, 5-26.

Inoguchi, T. 2013. "The 'Clash of Civilizations' Faces Evidence-Based Perusal." E-International Relations. 19 February. At https://www.e-ir.info/2013/o2/19/the -clash-of-civilizations-faces-evidence-based-perusal/. Accessed 26/10/202O. 
Ismail, F. 2011. "The Nahdlatul Ulama: Its Early History and Contribution to the Establishment of Indonesian State." Journal of Indonesian Islam. 5:2, 247-282.

Kaptein, N. 1997. The Muhimmat al-Nafäis: A Bilingual Meccan Fatwa Collection for Indonesian Muslims from the End of the Nineteenth Century. Jakarta: INIS.

Laffan, M.F. 2005. "The Fatwa Debated? Shura in One Indonesian Context." Islamic Law and Society. 12:1, 93-121.

Mahfudz, Sahal. 2003. Nuansa Fiqih Sosial. Yogyakarta: LKiS.

McGregor, E.K. 2009. "Confronting the Past in Contemporary Indonesia: The Anticommunist Killing of $1965^{-66}$ and the Role of Nahdlatul Ulama." Critical Asian Studies. 41:2, 195-224.

Mietzner, M. 2001. “Abdurrahman's Indonesia: Political Conflict and Institutional Crisis." In G. Lloyd and S. Smith eds, Indonesia Today: Challenges of History. Singapore: Research School of Pacific and Asian Studies/Institute of Southeast Asian Studies, 29-44.

Nakamura, M. 1981. "The Radical Traditionalism of the Nahdlatul Ulama in Indonesia: A Personal Account of the 26th National Congress, June 1979, Semarang." Southeast Asian Studies 19: 187-204.

Ricklefs, M.C. 1991. A History of Modern Indonesia Since c. 1200. Stanford, CA: Stanford University Press.

Rumadi. 2015. Islamic Post-Traditionalism in Indonesia. Singapore: ISEAS - Yusof Ishak Institute.

Saenong, Faried F. (Forthcoming). "KUPI: Congress of Indonesian Women's Ulama." In S. Joseph (ed.), Encyclopedia of Women and Islamic Culture, revised edition. Leiden and Boston: Brill.

Saenong, Faried F. 2016. "Women's Religious Education: Indonesia." In Suad Joseph (ed.), Encyclopedia of Women and Islamic Culture. Leiden: Brill.

Turmudi, E. ed. 2003. Nahdatul Ulama: Ideology, Politics, and the Formation of Khaira Ummah. Jakarta: LP. Ma'arif NU.

Wahid, M. 2001. "Post-tradisionalisme Islam: Gairah Baru Pemikiran Islam di Indonesia." Tashwirul Afkar 10.

Woodward, M. 1996. Toward a New Paradigm: Recent Development in Indonesian Islamic Thought. Arizona State University.

Zahro, A. 2004. Tradisi Intelektual NU: Lajnah Bahtsul Masa'il 1926-1999. 